\title{
Eliminação
}

\section{de substâncias perigosas do curriculum escolar e das escolas}

A nível dos ensinos secundários e complementar, o tipo de experiências realizadas em aulas de química e a selecção e gestão dos reagentes apropriados constituem dois dos meios mais importantes para garantir a existência de um ambiente de trabalho seguro nas escolas.

Os professores de química devem informar-se do benefício/risco de produtos químicos seleccionados para inclusão em trabalhos a realizar nas aulas laboratoriais. Não parece, até agora, ter sido dada qualquer atenção a essa avaliação benefício/risco por parte dos responsáveis do Ministério da Educação. Assim, nos programas oficiais constata-se que é sugerida a utilização de benzeno numa experiência destinada à demonstração do carácter aromático de uma substância orgânica; ora é sabido que o benzeno é um produto altamente cancerígeno, com efeitos cumulativos (VLT 100 ppm) e que o seu uso está interdito nas escolas inglesas e francesas. A referida experiência pode ser executada substituindo-se o benzeno por tolueno, 10 vezes menos tóxico (VLT $10 \mathrm{ppm}$ ), e sem que haja perda dos objectivos a atingir.

Perante esta situação, os professores de química deverão, na ausência de directivas nacionais emanadas pelas autoridades competentes, ter em conta as seguintes questões, antes de implementarem a realização de qualquer trabalho de laboratório:

1 - Avaliação dos perigos reais ou potenciais decorrentes da utilização dos produtos químicos necessários ao trabalho em causa;

2 - Percepção da importância do objectivo educacional que a experiência pretende atingir;

3 - Existência (ou ausência) de processos alternativos para atingir esse objectivo e/ou de substituintes químicos mais seguros;

4 - Decisão sobre se a experiência se destina a ser realizada pelos alunos ou apenas executada pelo professor como demonstração;

5 - Maturidade e/ou competência dos alunos;

6 - Existência (ou ausência) de condiçōes para a execução da experiência no laboratório (ex.: ventilação adequada, hotes, local de armazenagem adequado para os produtos químicos, equipamento protector);

7 - Decisão sobre a inclusão (ou exclusão) da experiência do curriculum académico.

Tem-se verificado que muitos professores terminam os seus cursos apenas com uma ideia vaga quanto aos perigos envolvidos em certas experiências e na utilização de determinados produtos químicos. Infelizmente desconhece-se a existência de estatísticas ou registos nacionais de acidentes registados em escolas em consequência da utilização de produtos químicos perigosos. O Boletim da Sociedade Portuguesa de Química publicou já um formulário para inquérito sobre as condições de segurança em estabelecimentos de ensino e laboratórios de investigação; foi reduzidíssimo o número de respostas recebido. As fichas de registo de acidentes aí incluídas, e de que se pedia o envio de uma cópia preenchida à Sociedade Portuguesa de Química sempre que se verificasse um acidente, nunca foram remetidas para a Sociedade. A verdade é que as condições de segurança nas escolas continuam a ser más e que os acidentes acontecem.

Torna-se necessário tomar medidas a nível nacional para alertar os professores quanto à segurança nos laboratórios escolares, e em particular quanto a quais os produtos químicos que representam um perigo potencial superior aos méritos da sua inclusão no curriculum académico, e sobre como devem as escolas que possuem esses produtos indesejáveis proceder à sua eliminação.

Um estudo efectuado nas escolas do Estado de Iowa (E.U.A.) entre 1978 e 1981 deu origem a uma lista de cerca de 230 substâncias que devem ser excluídas dos trabalhos práticos por o seu valor educacional não poder justificar os perigos potenciais envolvidos na sua utilização, e que consequentemente devem ser eliminadas das instalações escolares. Entre essas substâncias figuram o ácido pícrico, o ácido perclórico, o ácido fluorídrico, os cianetos, o fósforo e o potássio.

Em Portugal, e na ausência de directivas nacionais, um estudo deste tipo estará dependente da iniciativa de uns poucos professores e investigadores mais sensíveis aos problemas da segurança. Sugere-se as etapas a seguir na elaboração de um plano para eliminação de substâncias perigosas:

1 - Elaboração da lista de todos os produtos químicos utilizados nas escolas portuguesas desde 1960;

2 - Caracterização desses produtos químicos do ponto de vista dos perigos, reais ou potenciais, que envolvem;

3 - Elaboração da lista dos produtos a serem excluídos dos trabalhos experimentais;

\footnotetext{
a Departamento de Tecnologia de Indústria Química (LNETI), Estrada das Palmeiras, 2745 Queluz.
} 
4 - Inventariação nacional desses produtos;

5 - Solicitação aos fabricantes desses produtos de informação quanto ao seu modo de eliminação;

6 - Elaboração de folhas informativas sobre os métodos de destruição desses produtos químicos e envio dessas folhas a todas as escolas portuguesas.

Até que uma tal acção possa produzir os seus frutos, os professores devem ser encorajados a realizar inventários regulares dos armazéns das escolas (e de todas as outras dependências escolares em que eventualmente possam encontrar-se produtos químicos), e a remover os produtos desnecessários. Os produtos altamente voláteis ou perigosos só devem ser adquiridos em quantidade suficiente para um ano escolar. Outra precaução importante é a indicação, em cada embalagem de um produto químico, da data da sua aquisição e da data em que foi aberta, bem como a verificação periódica do estado de conservação das embalagens e sua imediata substituição sempre que se detectem sinais de deterioração. Se se verificar a inexistência de equipamento de segurança adequado, deverá considerar-se seriamente a exclusão das substâncias perigosas do programa escolar.

Para que esta acção de segurança possa ser levada a cabo, solicita-se aos professores de química que entrem em contacto com a Secção de Segurança da Sociedade Portuguesa de Química, enviando o boletim seguinte devidamente preenchido.

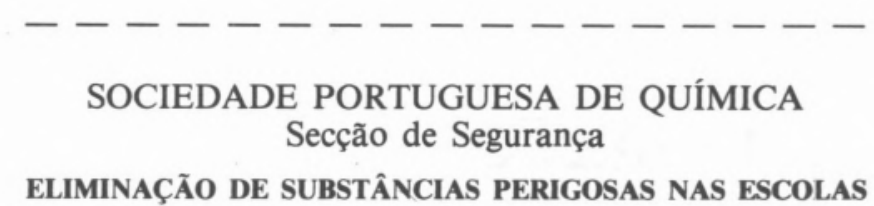

1. Nome

2. Escola

3. Morada

4. Telefone

5. Tipo de contribuição/colaboração que posso prestar:

6. Sugestões adicionais relacionadas com acção destinada à eliminação de substâncias perigosas nas escolas:

7. Data. $/ \ldots \ldots \ldots+\ldots / \ldots \ldots \ldots . .$.

8. Assinatura (legível). 